\title{
SELF-PERCEPTION OF COMPETENCE IN CHILDREN FROM SOCIALLY VULNERABLE CONTEXTS, ASSISTED AND UNASSISTED BY SOCIAL SPORTS PROJECTS
}

\author{
Glauber Carvalho Nobre ${ }^{1,2}$, Paulo Felipe Ribeiro Bandeira ${ }^{1}$, Maria Helena da Silva Ramalho3, \\ Francisco Salviano Sales Nobre ${ }^{4}$, Nadia Cristina Valentini ${ }^{5}$
}

\begin{abstract}
Introduction: practising sport contributes tothe reinforcement of important psychological features such as self-perception of competence, especially when participants are children from socially vulnerable contexts. Objective: to compare the socially vulnerable children's self-perception of competence, assisted and unassisted by social sports projects. Method: a total of 235 children (male and female), aged between seven and ten years, participated in this comparative study. They were divided into two groups: one group was formed by 106 children participating in social sports projects; the other was 129 children who did not participate in social sports projects. The selfperception of competence was assessed by the Brazilian version of the Self-Perception Profile for Children. We used a three-way ANOVA to assess the possible interaction effect between gender, age and group (children assisted and unassisted) in the different dimensions of perceived competence. Results: The children attending sports projects reported higher overaL global self-worth $\left.(F 1.234)=6,132, p=0.014, \eta^{2}=0.026\right)$. It was observed that there was an effect of interaction between the variable age $x$ group $\left.(F 1,234)=6.673, p=0.010, \eta^{2}=0.029\right)$ on the self-perception of social acceptance. There were no significant effects of group on the other dimensions of selfperception of competence. Conclusion: the children participatingin social sports projects showed more self-perception in terms of social acceptance and self-concept compared to non participatory children. This project does not help in other dimensions of self-perception.
\end{abstract}

Keywords: perceived competence, children, sport.

\section{INTRODUCTION}

During childhood, involvement in systematic sport practices contributes to strengthening of the self-perception of competence, which is configured as an important mediator of the motivation for learning ${ }^{1-3}$ and permanence of children in physical and sports activities ${ }^{4-6}$. Motor practices, when driven properly, strengthen the interest of children to gain mastery in motor skills ${ }^{7}$, assist in the establishment of social relations ${ }^{8}$, and strengthen the child's autonomy and self-confidence, important factors for child development ${ }^{3}$.

Numerous social projects with a focus on sport have been deployed in Brazil to promote the development of children ${ }^{9,10}$. In general, these projects aim to improve the quality of life, physical abilities and motor skills, social values, self-esteem development and motivation to attend sports, mainly aimed at children in situations of risk or social vulnerability ${ }^{11,12}$. The social vulnerability condition predisposes children to build a negative view of themselves and/or of their capacity ${ }^{13}$. Social sports projects can assist children in strengthening or building positive perceptions about their own skills (social, cognitive and motor) ${ }^{7}$.

Previous research on the topic has reported conflicting results regarding the benefits of social sports projects for children's self-perception of competency. ${ }^{14-17}$ Sports projects seem to have limited, or even a lack of impact, in important dimensions such as the perception of cognitive competence, behavioural conduct, physical appearance ${ }^{14,15}$ and self-concept ${ }^{16}$ among children. At the moment, only the study conducted by Grisa ${ }^{14}$ has reported that children participating in social

\footnotetext{
1 Doutorando, Universidade Federal do Rio Grande do Sul (UFRGS) - Porto Alegre (RS), Brasil.

2 Instituto Federal de Educação, Ciências e Tecnologia do Ceará. (IFCE) - Fortaleza (CE), Brasil.

3 Doutora, Universidade Federal de Juiz de Fora (UFJF) - Juiz de Fora (MG), Brasil.

4 Doutor, Instituto Federal de Educação, Ciências e Tecnologia do Ceará (IFCE) - Fortaleza (CE), Brasil.

5 PhD,UFRGS - Porto Alegre (RS), Brasil.

Corresponding author: Glauber Carvalho Nobre. E-mail: glauber_nobre@hotmail.com
}

Suggested citation: Nobre GC, Bandeira PFR, Ramalho MHS, Nobre FSS, Valentine NC. Self-perception of competence in children from socially vulnerable contexts, assisted and unassisted by social sports projects. Journal of Human Growth and Development. 25(3): 271-276. Doi: http://dx.doi.org/10.7322/jhgd.97673

Manuscript submitted Oct 22 2014, accepted for publication Dec 192014. 
sports projects presented significantly higher selfperception of affective competence and motor skills compared to children who have not participated.

Research on the self-perception of competence in Brazilian children from socially vulnerable contexts is still emergingand does not clarify whether participation in social sports projects assists in strengthening this variable, in particular in terms ofthe gender and age of the children. Therefore, it is necessary to conduct more research on the topic. In light ofthis, the objective is to compare the self-perception of competence in children assisted and not assisted by social sports projects.

\section{METHODS}

\section{Participants}

In this causal comparative study, 235 children participated, of both genders, aged between seven and ten years, coming from socially vulnerable contexts located in the coastal region, the mountainous region and the border of the State of Ceará, Brazil. Of these children, 106 (30 girls and 28 boys of 7-8 years; 22 girls and 26 boys of 9-10 years) were assisted by social projects with a focus on sport and participated for more than six uninterrupted months. The remaining 129 children ( 20 girls and 32 boys aged $7-8$ years; 26 girls and 51 boys aged $9-10$ years) were not assisted by social sports projects. All the children were from public schools which do not provide physical education classes in the initial grades. The children were properly enrolled and attended school regularly and did not have any kind of physical disability or known history of neurological disorders.

\section{Characteristics of social sports projects}

Of the 106 children assisted by social sports projects, 27 were part of a programme linked to the municipal public administration, 26 part ofa project of an athletic association which is a public institution and 53 part of a programme offered by a private entity devoted to social services. A feature common to these projects, irrespective of the socio-geographical or physical area in which they were set, was the predominance in offering a sport (futsal) for boys, dance for girls, and recreation activities for both genders. Classes were taught by physical education teachers twice weekly with an average duration of two hours per session. The children that were not assisted by social sports projects had some commonality with the assisted children: they resided within the same context of social vulnerability and studied at the same schools.

\section{Instruments}

The children's perception of their competence was evaluated by means of the Brazilian version of the Self-Perception Profile for Children ${ }^{18,19}$, validated by Valentini et a/20. The Brazilian version, called the Self-Perception Scale for Children (SPC), is a questionnaire that assesses five specific competence fields: cognitive competence, emotional competence, motor competence, physical appearance and behavioural conduct, in addition to the global self-worth. Each domain contains six questions organized into structured alternative answers reminiscent of a four point Likert scale. The SPC presented content validity coefficients within the acceptable values (clarity between 0.91 and 0.68 and relevance between 0.86 and 0.89 ) forthe six dimensions and forthe overall score of the instrument. The test-retest scores were significant and ranged from $r=0.54$ to $r=0.83$. The indices of confirmatory factor analysis were satisfactory for the general sample $\left(\mathrm{x}^{2} / \mathrm{gl}=4.33\right.$; non-normed fit index $=0.958$; comparative fit index $=0.967$; Tucker-Lewis index of fit $=0.962)^{20}$.

\section{Procedures}

This study was approved by the Committee of Ethics in Research with Human Beings (2008018 protocol). After the consent of the education departments regarding the contexts involved in the research, meetings were held with managers of selected schools to discuss with them the procedures adopted in the survey as well as to gain consent for use of the physical space. Meetings were also held with parents and/or those responsible for the children in order to explain the procedures to be adopted in the psychological assessment and to procure their consent to the participation of the children in the research. The children were selected by convenience and only those whose parents or legal guardians signed the informed consent were allowed to take part.

The SPC was administered on an individual basis, in appropriate locations ${ }^{21}$. The evaluators were trained in its application and the average time taken was 20 minutes. The perception of competence in the five dimensions and the global selfworth came from the sum of the scores of issues addressed on the scale. The values of the sum of the issues were standardized as the "z score". Values of $\mathrm{z}$ scores ranging between -1 and +1 were considered as "moderate" PCM. Values less than -1 and bigger than +1 were considered as "low" and "high" PCM, respectively. The classification was based on the personal characteristics of the sample, since there are still no cohort points described in the literature. Similar methods are being used in other researchs ${ }^{2-23}$.

\section{Statistical analysis}

Statistics of average and standard deviation were used. In addition, frequency statistics were employed, and percentages relevant to the classification of the dimensions of the self-perception of competence. A three-way analysis of variance was used, considering the factor "group" at two levels (participants and non-participants of social sports projects); "gender" at two levels (male and female); and "age" at two levels (7-8 years and 9-10 years). Independent sample " $t$ " test were used where significant main effects or interactions had been identified. The significance level adopted was $\alpha<0.05$. 


\section{RESULTS}

The results of the levels of the dimensions of children's self-perception of competence can be viewed in Table 1. It was noted that regardless of gender or age, the majority of assisted and non- assisted children presented moderate level perceptions in the six dimensions investigated. In relation to other levels (low and high), the highest percentages were observed for the condition of lower self-perception of competence of social acceptance in younger boys who participated in sports projects $(32.1 \%)$.

Table 1. Self-perceived competence among groups of children dimensions categorization $\mathrm{f}(\%)$

\begin{tabular}{|c|c|c|c|c|c|c|c|c|c|c|c|c|}
\hline \multirow[b]{3}{*}{$7-8$ years } & \multicolumn{6}{|c|}{ Male } & \multicolumn{6}{|c|}{ Female } \\
\hline & \multicolumn{3}{|c|}{ Assisted } & \multicolumn{3}{|c|}{ Non-assisted } & \multicolumn{3}{|c|}{ Assisted } & \multicolumn{3}{|c|}{ Non-assisted } \\
\hline & Low & Moderate & High & Low & Moderate & High & Low & Moderate & High & Low & Moderate & High \\
\hline Cognitive competence & $5(17,9)$ & $18(64,3)$ & $5(17,9)$ & $6(18)$ & $19(59,4)$ & $7(21,9)$ & $6(20,0)$ & $18(60,0)$ & $6(20)$ & $5(25,0)$ & $11(55,0)$ & $4(20,0)$ \\
\hline Social acceptance & $9(32,1)$ & $17(60,7)$ & $2(7,1)$ & $4(12,5)$ & $22(68,8)$ & $6(18,8)$ & $6(20,0)$ & $20(66,7)$ & $4(13,3)$ & $4(20,0)$ & $14(70,0)$ & $2(10,0)$ \\
\hline Motor competence & $4(14,3)$ & $24(85,7)$ & - & $4(12,5)$ & $22(68,8)$ & $6(18,8)$ & $8(26,7)$ & $15(50,0)$ & $7(23,3)$ & $3(16,0)$ & $16(80,0)$ & $1(5,0)$ \\
\hline Physical appearance & $7(25)$ & $14(50,0)$ & $7(25)$ & $5(15,6)$ & $23(71,9)$ & $4(12,5)$ & $7(23,3)$ & $20(66,7)$ & $3(10,0)$ & $4(20,0)$ & $15(75,0)$ & $1(5,0)$ \\
\hline Behavioral conduct & $6(21,4)$ & $20(71,4)$ & $2(7,1)$ & $4(12,5)$ & $21(65,6)$ & $7(21,9)$ & $5(16,7)$ & $19(63,3)$ & $6(20,0)$ & $3(15,0)$ & $13(65,0)$ & $4(20,0)$ \\
\hline Self-concept & $4(14,3)$ & $16(57,1)$ & $8(28,6)$ & $5(15,6)$ & $25(78,1)$ & $2(6,4)$ & $5(16,7)$ & $20(66,7)$ & $5(16,7)$ & $3(15,0)$ & $16(80,0)$ & $1(5,0)$ \\
\hline \multicolumn{13}{|l|}{$9-10$ years } \\
\hline Cognitive competence & $6(23,1)$ & $15(57,7)$ & $5(19,2)$ & $7(13,7)$ & $34(66,7)$ & $10(19,6)$ & $4(18,2)$ & $14(63,2)$ & $4(18,2)$ & $5(19,2)$ & $17(65,4)$ & $4(15,4)$ \\
\hline Social acceptance & $3(11,5)$ & $15(57,7)$ & $8(30,8)$ & $13(25,5)$ & $31(60,8)$ & $7(13,7)$ & $4(18,2)$ & $13(59,1)$ & $5(22,7)$ & $5(19,2)$ & $19(73,1)$ & $2(7,7)$ \\
\hline Motor competence & $6(23,1)$ & $15(57,7)$ & $5(19,2)$ & $9(17,6)$ & $36(70,6)$ & $6(11,8)$ & $6(27,3)$ & $11(50,0)$ & $5(22,7)$ & $4(15,4)$ & $19(73,1)$ & $3(11,5)$ \\
\hline Physical appearance & $2(7,7)$ & $20(76,9)$ & $4(15,4)$ & $9(17,6)$ & $30(58,8)$ & $12(23,5)$ & $4(18,2)$ & $14(63,2)$ & $4(18,2)$ & $2(7,7)$ & $18(69,2)$ & $6(23,1)$ \\
\hline Behavioral conduct & $5(19,2)$ & $14(53,8)$ & $7(26,9)$ & $9(17,6)$ & $32(62,7)$ & $10(19,6)$ & $4(18,2)$ & $11(50,0)$ & $7(31,8)$ & $2(7,7)$ & $20(76,9)$ & $4(15,4)$ \\
\hline Self-concept & - & $23(88,5)$ & $3(11,5)$ & $10(19,6)$ & $31(60,8)$ & $10(19,6)$ & $2(9,1)$ & $14(63,2)$ & $6(27,3)$ & $7(26,9)$ & $14(53,8)$ & $5(19,2)$ \\
\hline
\end{tabular}

In the non-assisted group, the largest percentages were also observed in the condition of lower self-perception of social acceptance (25.5\%), but in older boys. High self-concept was reported in $28.6 \%$ of $7-8$ years boys assisted by projects. Lower self-perception competence was reported in $27.6 \%$ of younger girls and $27.3 \%$ of girls aged 9-10 years who attended social sports projects.

The mean and standard deviation of each dimension of the SPC in groups are contained in table 2, in the five dimensions of perception of competence evaluated: cognitive competence, affective competence, motor competence, physical appearance, behavioural conduct, and, alsoin selfconcept.
A significant interaction effect was observed between the variables group and age $F(1,234)=$ $\left.=6.673, p=0.010, \eta^{2}=0.029\right)$ regarding social acceptance. Independent sample t-test indicated that the younger children ( $7-8$ years) not assisted by sport projects realized to be more competent than the assisted ones ( $t=2.691, p=0.008)$. Instead, the older children (9-10 years) attended by the sports projects showed greater awarenessof social acceptance $(t=-2.049, p=0.043)$ when compared to the non-assisted children (see Table 2 ). In this study, we also observed a significant effectof group on the self-concept of children $\left.F(1,234)=6.132, p=0.014, \eta^{2}=0.026\right)$. The children assisted by the projects indicated a significantly higher average compared

Table 2: Media and standard deviation auto dimensions of the perception of competence in general and according to gender and age

\begin{tabular}{|c|c|c|c|c|c|c|c|c|c|c|}
\hline & \multicolumn{2}{|c|}{ Male } & \multicolumn{2}{|c|}{ Female } & \multicolumn{2}{|c|}{$7-8$ years } & \multicolumn{2}{|c|}{$9-10$ years } & \multicolumn{2}{|c|}{ General } \\
\hline & Assisted & Non-assisted & Assisted & Non-assisted & Assisted & Non-assisted & Assisted & Non-assisted & Assisted & Non-assisted \\
\hline Cognitivecompetence & $16.3(3.2)$ & $16.4(3.4)$ & $17.0(3.0)$ & $16.9(2.7)$ & $17.0(3.1)$ & $16.9(3.1)$ & $16.2(3.0)$ & $16.4(3.2)$ & $16.5(3.1)$ & $16.6(3.2)$ \\
\hline Social acceptance & $16.3(2.9)$ & $16.1(2.9)$ & $16.4(2.6)$ & $16.4(2.3)$ & $16.1(2.7)^{\mathrm{a}}$ & $17.0(2.7)^{\mathrm{a}}$ & $16.7(2.7)^{b}$ & $15.7(2.6)^{b}$ & $16.3(2.7)$ & $16.2(2.7)$ \\
\hline Motor competence & $15.1(2.9)$ & $15.8(2.9)$ & $15.0(3.4)$ & $15.5(3.3)$ & $15.2(3.0)$ & $16.1(3.1)$ & $14.9(3.3)$ & $15.4(2.9)$ & $15.0(3.1)$ & $15.7(3.0)$ \\
\hline Physical appearance & $16.6(3.6)$ & $16.9(3.7)$ & $17.6(3.4)$ & $17.1(3.2)$ & $17.5(3.8)$ & $17.2(3.3)$ & $16.7(3.3)$ & $16.8(3.8)$ & $17.1(3.6)$ & $17(3.5)$ \\
\hline Behavioral conduct & $16.1(3.0)$ & $16.3(3.0)$ & $17.3(3.0)$ & $17.1(2.2)$ & $16.7(3.1)$ & $16.8(3.0)$ & $16.8(3.0)$ & $16.4(2.7)$ & $16.7(3.1)$ & $16.6(2.8)$ \\
\hline Self-concept & $17.9(2.5)$ & $17.3(2.6)$ & $18.3(2.8)$ & $17.1(2.8)$ & $17.9(3.1)$ & $17.1(2.4)$ & $18.3(2.1)$ & $17.3(2.9)$ & $18.1(2.8)^{c}$ & $17.3(2.7)^{c}$ \\
\hline
\end{tabular}

$a, b, c$ statisticall significant difference $p<0,05$.

\section{DISCUSSION}

Most children, assisted and non-assisted, presented moderate levels of self-perception of competence in the dimensions assessed in this study, regardless of gender or age. Other studies have reported similar results in which children of different ages and both genders reported perceptions of moderate competen$\mathrm{cy}^{3,17,24-26 .}$ 
Strategies such as recognition of achievements and results and strengthening of social interactions allowthe establishment of evaluation criteria which make children more positive and realistic about their own skills ${ }^{27,28}$. It is important to reflect on the implementation of these strategies in order to reinforce the positive and realistic selfperception of competence in children, since the sentiment of competence leads to an increase in intrinsic motivation to get involved in activities that challenge them, enabling them to persist in a task and achieve a degree of mastery ${ }^{2,7}$.

In this study, it was possible to observe that, in general, children attending social sports projects demonstrated a higher self-concept compared to those not assisted by sporting projects.

Other studies have reported differences between participants and non-participants of children's social sports projects ${ }^{14,16}$. Sports practice can help children to strengthen theirself-concept ${ }^{7}$, this being particularly important for children from socially vulnerable contexts. The condition of instability and reduced access to economic and cultural opportunities may predispose these children to forma negative view of themselves ${ }^{7}$; sports programmes that provide equal social access to environments hither to inaccessible can be important promoters of development.

It was identified in this study that the two groups did not differ in their self-perception of competence, except in terms of social acceptance. In this dimension, the 9-10 year old children attending social sports projects realized they were more accepted by their peers and were also more competent in their social interaction than those of the same age who did not participate. Grisa14 also reported higher self-perception of social acceptance in older children (11-12 years) who participated in sports projects compared to those of the same age who did not participate. Research has reported that participation in sports activities increases social relations and cooperation ${ }^{29}$, improves interpersonal relationships with peers ${ }^{30}$, and helps participants work in groups ${ }^{31}$ and make friends ${ }^{30}$. However, contrary to the trend observed in older children, the results of this study indicate that in younger children assisted by projects (7-8 years), the perception of social acceptance was lower than in non-assisted children. Possibly they feel more challenged by a competitive sports context: these children doubt their social ability $t$ develop friendships in a context that might be seen as selective.

It is possible that the actions developed in social projects, such as sports contexts, are insufficient to stimulate the self-perception of social acceptance in these younger children. The fact of being competent in this area leads the child to feel safe to engage in activities that require interaction with others, since social acceptance is related to the ability to get others to love him and to make friends ${ }^{2,19}$. In these programmes, it therefore becomes important to create opportunities for participation in small groups and greater interaction among children so that they understand that they are accepted in the social sports group.
In general, the comparative analysis indicatesthat regardless of gender orage, children botha ssisted and non-assisted by sports projects do not differ in their self-perception in the cognitive, motor competence, physical appearance and behavioural conduct dimensions. Similar results were also reported in previous surveys ${ }^{14,15}$. In the study conducted by Grisa 14 and Grisa and Gaion ${ }^{15}$, no differences were observed in the cognitive competence, the behavioural conduct or the physical appearance of the assisted children compared to those who were non-assisted. These results, therefore, raise important questions about the way that social sports projects have been implemented and how they can assist children to become more competent and, consequently, realize more competence.

It is important to consider that social sports projects can create strategies that help children to appreciate themselves, stimulating important competent cognitive processes such as attention, intelligence, memory, decision-making, problemsolving ${ }^{32}$, and are an important means by which to reinforce concepts from different areas of knowledge such as language, mathematics, humanities and others ${ }^{33}$. These can also help participants to realize their own conduct and the conduct of others, and consequently to adopt behaviours that enable compliance with rules and norms leading to a healthy social coexistence. The assumption of appropriate instructions and feedback provided by teachers in practice, as well as challenges appropriate to developing bodies, can optimize performance in tasks related to sports practice, making these children more competent and therefore leading them to judge more accurately their own competence.

Considering the self-perception of physical appearance, social sports projects can help children understand and respect differences in their body characteristics and those of their peers, helping them to use parameters to understand who they are, to understand themselves as individuals and to build a positive and realistic view of themselves. Furthermore, children who are more satisfied with their body perceive themselves as more competent in motion tasks (e.g. physical education classes) and are physically more active ${ }^{34}$. The self-perception of competence results reported by the children in this comparative study raises important issues, especially in the context of motor practice. Inefficient strategies employed by social sports projects can hinder the acquisition of benchmarks that allow children to assess their current motor skills with greater precision, and consequently reflect negatively on engagement in targeted motor activities ${ }^{3,35-38}$.

The results of this study suggest that children participating in social sports projects present a higher degree of social acceptance and self-perception than children who do not attend sporting projects. In addition, there was a strengthening of other important dimensions of self-perception of competence, including the cognitive, motor, physical appearance and behavioural conduct dimensions, also important to proper child development. 
Thus, it is important to reflect on the way motor-driven practices are designed, organized and implemented for the more effectivedevelopment of self-perception of competence in children. It is essential that the experiences of learning in children's sports comprise strategies that strengthen the positive construction guiding children to greater involvement in challenges,persistence in the face of difficulties, tenacity, adoption of goals and high expectations of success, encouraging the children

\section{REFERENCES}

1. Siedentop D. Sport education: Quality Pe through positive sport experiences. Champaign: Human Kinetics Publishers; 1994.

2. Harter S. The Construction of the Self: developmental and sociocultural foundation. 2 ed. New York:Guilford Press; 2012.

3. Valentini NC. Influência de uma intervenção motora no desempenho motor e na percepção de competência de crianças com atrasos motores. Rev Paul Edu Fís. 2002;16(1):61-75.

4. Cairney J, Kwan MYW, Velduizen S, Hay J,Bray SR, FaughtBE. Gender, perceived competence and the enjoyment of physical education in children: a longitudinal examination. Int J BehavNutrPhys Act. 2012; 9(26):DOI: http:// dx.doi.org/10.1186/1479-5868-9-26

5. Valentini NC. Competência percebida: considerações para promover a aprendizagem. In: Krebs RJ, Ferreira Neto CA. Tópicos em desenvolvimento motor na infância e adolescência. Rio de Janeiro: Lecsu; 2007; p.137-57.

6. Souza MS, Valentini NC. A influência do suporte social e da percepção de competência motora na prática de atividades físicas: um estudo de revisão. RevThema.2014;11(1): 103-113.

7. Valentini NC. Percepções de competência, autoconceito e motivação: considerações para a prática esportiva. In: Oliveira AAB, Perem GL. Fundamentos Pedagógicos para o programa segundo tempo. Ministério dos Esportes: Porto Alegre: UFRGS; 2008; p.113-121.

8. Weinberg RS, Gould D. Fundamentos da Psicologia do esporte e do exercício. Porto Alegre: Artmed; 2008.

9. Instituto de Pesquisa Econômica Aplicada (IPEA). Brasil em desenvolvimento: Estado, Planejamento e políticas públicas. Brasília: IPEA, 2009.

10. Brasil. Ministério do Esporte. Secretaria Nacional de Esporte Educacional. Diretrizes do Programa Segundo Tempo. Brasília: 2009.

11. Machado PX, Cassepp-borges V, Dell 'aglio DD, Koller SH. O impacto de um projeto de educação pelo esporte no desenvolvimento infantil. PsicolEsc Edu. 2007; 11(1): 51-62. DOI: http:/ /dx.doi.org/10.1590/S1413-85572007000 100006

12. Hirama LK, Montagner PC. Algo para além de tirar da rua: o ensino do esporte em projeto socioeducativo. RevBrasCiênc Esporte.2012;34(1): 149-164. DOI: http:// dx.doi.org/10.1590/S0101-32892012000 100011 toopen them selves up to new challenges and, finally, to becomemore competent and confident in their own abilities.

Future studies may consider the influence of the activities implemented in projects of this nature, in addition to investigating the influence of sports initiation and motor methodologies on the self-perception of children's skills in different contexts. These limitations are assumed in this study.

13. Pereira SEFN. Crianças e adolescentes em contexto de vulnerabilidade social: articulação de redes em situação de abandono ou afastamento do convívio familiar. [cited 2013Jun 03] Available from: <www.aconchegodf.org.br/biblioteca/artigos/artigo01.pdf >.

14. Grisa RA. Percepção de Competência e Desempenho Motor: um estudo com escolares. Dissertação (Mestrado) - Departamento de Educação Física da Universidade Estadual de Maringá. Maringá:2008.

15. Grisa RA, Gaion PA. Percepção de competência motora e desempenho motor: quem pratica esporte é mais competente? Rev Educ Física UEM. 2007; 18(sup): 37-39.

16. Marques ERD. Projetos sociais esportivos: um estudo das relações entre o esporte e o autoconceito Dissertação (Mestrado) - Escola de Educação Física e Esporte da Universidade de São Paulo. São Paulo: 2012.

17. Brauner LM. Projeto Social Esportivo: Impacto no desenvolvimento motor, na percepção de competência e na rotina de vida dos participantes. Dissertação (Mestrado) - Escola de Educação Física da Universidade Federal do Rio Grande do Sul. Porto Alegre: 2010.

18. Harter S. Manual for the Self-Perception Profile for Children. Denver: Universityof Denver; 1985.

19. Harter S. Self-Perception Profile for Children: Manual and Questionnaires. Denver: Denver University: 2012.

20. Valentini NC, Villwock G, Vieira LF, Vieira JLL, Barbosa MLL. Validação Brasileira da Escala de Autopercepção de Harter para Crianças. PsicolReflex Crítica. 2010; 3(3): 411-19.

21. Guimarães FAB, Assis CDA, Vieira MEB, Formiga CKMR. Evaluation of teaching materials prepared for guidance of caregivers and day care teachers on child development. J Hum Growth Dev. 2015; 25(1): 27-40. DOI: http:// dx.doi.org/10.7322/jhgd.96764

22. Almeida G, Valentini NC, Berleze A. Percepções de competência: um estudo com crianças e adolescentes do ensino fundamental. Movimento. $2009 ; 15(1)$ : 71-97.

23. Souza MS, Spessato BC, Valentini NC. Percepção de competência motora e índice de massa corporal influenciam os níveis de atividade física? RevBrasCienc Mov. 2014; 22(2): 78-86.

24. Silva SR.Desenvolvimento motor, percepção de competência atlética e estado nutricional: um estudo com crianças entre 8 e 10 anos da rede pública de ensino. Dissertação (Mestrado) Departamento de Educação Física da Universi- 
dade Estadual de Maringá. Maringá: 2009.

25. Texeira CT. Aquisição de habilidades motoras aquáticas: um programa de intervenção estruturado como base na teoria de instrução para crianças jovens. Dissertação (Mestrado) Universidade Estadual de Maringá. Maringá: 2008.

26. Villwock G, Valentini NC. Percepção de competência atlética, orientação motivacional e competência motora em crianças de escolas públicas: estudo desenvolvimentista e correlacional. RevBrasEducFís Esporte. 2007;21(4):245-57. DOI: http://dx.doi.org/10.1590/S180755092007000400001

27. Valentini NC. Percepções de competência e desenvolvimento motor de meninos e meninas: um estudo transversal. Movimento. 2002;8(2):51-62.

28. Valentini NC, Rudisill M. Motivational Climate, Motor-Skill Development, and Perceived Competence: Two Studies of Developmentally Delayed Kindergarten Children. J Teach Phys Educ. 2004;23(3): 216-234.

29. Findlay LC, Coplan RJ. Come out and play: Shyness in childhood and the beneftis of organized sports participation. Can J Behav Sci. 2008; 40(3):153-161. DOI: http://dx.doi.org/ 10.1037/0008-400X.40.3.153

30. Holt NL, Kingsley BC, Tink LN, Scherer J. Benefits and challenges associated with sport participation by children and parents from lowincome families. Psychol Sport Exerc2011, 12:490-499. DOI: http://dx.doi.org/10.1016/ j.psychsport.2011.05.007
31. Wiersma LD, Fifer AM. "The schedule has been tough but we think it's worth it": the joys, challenges, and recommendations of youth sport parents. J Leis Res.2008;40(4):505-530.

32. Matias CJ, Greco PR. Cognição e ação nos jogos esportivos coletivos. Ciênc Cogn. 2010; 15(1): 252-271.

33. Gallahue D,Donnelly FC. Educação Física Desenvolvimentista para todas as crianças. São Paulo: Phorte; 2008.

34. SallerhedAC, Apitzsch E, Råstam L, Ejlertsson G. Factors associated with young children's selfperceived physical competence and selfreported physical activity. Health Educ Res. 2008; 23(1):125-136.

35. Robinson $L$. The relationship between perceived physical competence and fundamental motor skills in preschool children.Child Care Health Dev. 2011; 37(4):589-96. DOI: http:// dx.doi.org/10.1111/j.1365-2214.2010. 01187. $\mathrm{x}$

36. Carroll B, Loumidis J. Children's perceived competence and enjoyment in physical education and physical activity outside school. EurPhysEdu Rev.2001;7(1):24-43.

37. Cordazzo STD, Vieira ML, Almeida AMT. Portuguese and brazilian children's play in school. J Hum Growth Dev. 2012; 22(1): 60-67.

38. Hansen J, Macarini SM, Martins GDF, Wanderlind $\mathrm{FH}$, Vieira ML. The play behavior and its implications for child development according to Evolutionary Psychology. Rev Bras Crescimento Desenvolv Hum. 2007;17(2):133-143.

\section{RESUMO}

Introdução: contextos de prática esportiva podem contribuir para o fortalecimento de características psicológicas importantes como a autopercepção de competência, sobretudo quando os participantes são crianças provenientes de contextos de vulnerabilidade social. Objetivo: comparar a autopercepção de competência de crianças em situação de vulnerabilidade social, assistidas e não assistidas por projetos sociais esportivos. Método: participaram deste estudo comparativo causal 235 crianças, de ambos os gêneros, com idade entre sete e 10 anos provenientes de diferentes contextos do Ceará - Brasil. As crianças foram divididas em dois grupos: Um grupo formado 106 por crianças que participavam de projetos sociais de cunho esportivo. O outro constituído por 129 crianças não assistidas por projetos sociais esportivos. A percepção de competência foi avaliada através da versão brasileira da Self-Perception Profile for Children. Utilizou-se uma análise de variância three way para avaliar o possível efeito de interação entre o gênero, idade e grupo (crianças assistidas e não assistidas) nas diferentes dimensões da percepção de competência. Resultados: as crianças assistidas reportaram maior auto conceito $\left.\left(F_{(1,234)}\right)=6,132 p=0,014 \eta^{2}=0,026\right)$. Observou-se efeito do grupo e da idade $\left.\left(F_{(1,234)}\right)=6,673 p=0,010 \eta^{2}=0,029\right)$ sobre a percepção de aceitação social. Não foram observados efeitos significativos do grupo nas demais dimensões da autopercepção de competência. Conclusão: crianças participantes dos projetos sociais esportivos mostraram maior autopercepção na aceitação social e no autoconceito comparadas as crianças não participantes. Os projetos não auxiliaram no fortalecimento das outras dimensões da autopercepção. Assim, é importante refletir sobre a implementação de metodologias, em projetos dessa natureza, que contemplem o desenvolvimento da autopercepção de competência neste público.

Palavras-chave: percepção de competência, crianças, esporte. 